\title{
Characteristics and Composition of a High Oil Yielding Castor Variety from Pakistan
}

\author{
Tarique Panhwar ${ }^{1}$, Sarfaraz Ahmed Mahesar, ${ }^{1, *}$, Abdul Waheed Mahesar ${ }^{2}$, \\ Aftab Ahmed Kandhro ${ }^{3}$, Farah Naz Talpur ${ }^{1}$, Zahid Hussain Laghari ${ }^{1}$, \\ Abdul Sattar Chang ${ }^{1}$ and Syed Tufail Hussain Sherazi ${ }^{1}$ \\ ${ }^{1}$ National Center of Excellence in Analytical Chemistry, University of Sindh, Jamshoro-76080, PAKISTAN \\ ${ }^{2}$ Institute of Information \& Communication Technology, University of Sindh, Jamshoro-76080, PAKISTAN \\ ${ }^{3}$ Dr. M. A. Kazi Institute of Chemistry, University of Sindh, Jamshoro-76080, PAKISTAN
}

\begin{abstract}
Keeping in view the versatile applications of castor oil in cosmetic, pharmaceutical and recently as renewable source, the present work is a step towards the commercialization of castor on large scale in Pakistan. The current study introduces a castor variety with high oil content. Initially seeds were physically examined for some physical parameters. Seed moisture, ash content and linear dimensions such as length, width and thickness were found to be $4.53 \%, 6.44 \%, 12.24 \mathrm{~mm}, 8.31 \mathrm{~mm}$ and $5.67 \mathrm{~mm}$, respectively. For oil extraction, Soxhlet method was used which resulted in the high oil content $54.0 \%$. For quality assessment of oil, physicochemical parameters were checked according to official standard AOCS methods and compared with ASTM specifications. The determined parameters were as follows; specific gravity $0.953 \mathrm{~g} / \mathrm{cm}^{-3}$, refractive index 1.431, viscosity $672.0 \mathrm{mPas} . \mathrm{s}$, moisture content $0.32 \%$, FFA $0.14 \%$, IV $83.61 \mathrm{gI} / 100 \mathrm{~g}$, PV $2.25 \mathrm{meq} / \mathrm{Kg}$ and SV $186.0 \mathrm{mgKOH} / \mathrm{g}$. Furthermore, fatty acid analysis of oil showed that, most abundant fatty acid was ricinoleic acid $94.59 \%$, followed by palmitic $0.31 \%$, linoleic $1.84 \%$, oleic (n-9) $2.05 \%$, oleic (n10) $0.22 \%$, stearic $0.45 \%$ and eicosenoic acid $0.53 \%$. The detected fatty acids were compared with registered variety and varieties of other regions.
\end{abstract}

Key words: castor seed, high oil content, physiochemical characteristics, fatty acids

\section{INTRODUCTION}

Castor is an important high-yield oilseed crop, which produces about $50 \%$ of oil by weight ${ }^{1)}$. It belongs to Euphorbiaceae family and botanically known as Ricinus communis $\mathrm{L}^{2}{ }^{2}$. The plant is grown or cultivated all over the world because of vast use of its oil in pharmaceutical, industrial and energy sector. Castor plant is tropical/subtropical and can be grown in warm temperate regions due to its tolerance to weather conditions ${ }^{3,4)}$. The average yield of castor seeds per hac is 1.1 ton, which can be increased on favorable conditions to 4-5 t, yielding a maximum of $2000 \mathrm{~kg}$ oil per hac ${ }^{5)}$.

Castor oil is pale yellow, non-volatile, viscous and nondrying in nature ${ }^{3)}$. The oil consist of unique fatty acid; ricinoleic acid which comprises of $90 \%$ of the total fatty acids. Other fatty acids include palmitic $0.7 \%$, oleic $2.8 \%$, linoleic $4.4 \%$, and linolenic acid $0.2 \%{ }^{6,7)}$ Ricinoleic acid is chemically known as 12-hydroxy-9-octadecenoic acid. The presence of hydroxyl group attributes to high viscosity, specific gravity and solubility in alcohols ${ }^{8)}$.

Castor oil has more than 700 industrial uses including applications in medicines, coatings, cosmetics, lubricants, fuel additives, biopolymers and recently in making biodies$\mathrm{el}^{9,10)}$.

Castor is cultivated on commercial scale in 30 countries for its oil, which has a worldwide demand of about 220,000 tons per year ${ }^{8)}$. Five major countries which contribute to global castor production include India, China, Russia, Brazil and Thailand. India is the largest exporter of castor oil which contributes to $70 \%$ of total exports ${ }^{11)}$.

Pakistan has the identity as an agricultural country where $70 \%$ population belongs to agricultural sector, but still millions of hectares are lying vacant and uncultivated due to water shortage ${ }^{12)}$. Therefore castor plant is drought tolerant and shows great potential to grow on such large area. In Pakistan, castor is cultivated on very small scale in Punjab and Baluchistan province but still large area of Sindh province is unutilized.

\footnotetext{
*Correspondence to: Sarfaraz Ahmed Mahesar, National Center of Excellence in Analytical Chemistry, University of Sindh, Jamshoro-76080, PAKISTAN

E-mail: mahesar_sarfaraz@yahoo.com

Accepted January 25, 2016 (received for review September 9, 2015)

Journal of Oleo Science ISSN 1345-8957 print / ISSN 1347-3352 online

http://www.jstage.jst.go.jp/browse/jos/ http://mc.manusriptcentral.com/jjocs
} 


\section{T. Panhwar, S. A. Mahesar and, A. W. Mahesar et al.}

Many studies have been conducted regarding the characterization of newer varieties of castor. Perdomo et $a l^{8}{ }^{8)}$ reported 7 Mexican varieties, while Algharib and Kotb ${ }^{13)}$ tested 4 Egyptian varieties of castor seeds. Another study carried out by Lavanya ${ }^{14)}$ from India has shown 15 castor genotypes in which fatty acid composition, oil content and their use in biodiesel production discussed. From Brazil 36 castor bean varieties were surveyed for oil and fatty acid composition for the analysis of variability ${ }^{15)}$. However, to our knowledge, no any literature is available regarding the characterization of Pakistani castor bean varieties. Since 1979 , castor seed cultivation is on continuous decline in the country ${ }^{16)}$. Province of Sindh has a fertile land and large area vacant for cultivation of such energy crop.

The present work introduces a newer variety with high oil yield and good quality oil, which could be helpful for initiating castor cultivation and could be the successful candidate among other inedible oil yielding plants for further use in industrial, medicinal and renewable purpose.

\section{MATERIALS AND METHODS}

\subsection{Reagents and sample collection}

All the chemicals and reagents used in the present work were purchased from E-Merck (Darmstadt, Germany). Castor seeds were collected from Dadu with geographical location (elevation $24 \mathrm{~m}$, latitude $26.73^{\circ} \mathrm{N}$, longitude $67.78^{\circ}$ E). The region has low humidity throughout the growing season, which is good sign of maximum oil yield by this crop $^{3)}$. The type of soil where the seeds harvested was nonsaline, non-sodic. The height of castor plant was 2-3 meters with ramified branch distribution. Castor seeds were packed in clean sampling bags and dried at room temperature. Seed shells were removed and after obtaining clean seeds, they were stored at normal temperature in the dark.

\subsection{Physical Characteristics of seeds}

Seed characteristics such as color, length, width, height, individual seeds weight and 100-seed weight were determined and represented in Table 1.

\subsection{Moisture and Ash content of seeds}

Determination of moisture content of seeds is very important while dealing with harvesting and storage procedures ${ }^{17)}$. Moisture and ash content of castor seeds were calculated according to AOCS methods, Aa 3-38 and Ba $5 a-49$, respectively ${ }^{18)}$.

\subsection{Oil Extraction}

Crude castor oil was extracted from seeds by Soxhlet extraction method. Clean seeds were crushed and $50 \mathrm{~g}$ of sample was carefully placed inside the Soxhlet extractor. About $400 \mathrm{~mL} n$-hexane was added to round bottom flask
Table 1 Physical characteristic of castor seed.

\begin{tabular}{lr}
\hline \multicolumn{1}{c}{ Parameter } & \multicolumn{1}{c}{ Castor seed } \\
\hline Moisture Content $(\%)$ & $4.53 \pm 0.19$ \\
Ash Content $(\%)$ & $6.44 \pm 0.23$ \\
Length $(\mathrm{mm})$ & $12.24 \pm 1.19$ \\
Width $(\mathrm{mm})$ & $8.31 \pm 0.01$ \\
Thickness $(\mathrm{mm})$ & $5.67 \pm 0.59$ \\
Individual seed weight $(\mathrm{g})$ & $0.38 \pm 0.07$ \\
100 -seed weight $(\mathrm{g})$ & $39.85 \pm 0.14$ \\
\hline $\mathrm{n}=3$ (mean $\pm \mathrm{SD})$ &
\end{tabular}

of $1 \mathrm{~L}$. The temperature of extraction process was set at $60^{\circ} \mathrm{C}$ and process continued for about 6 hours. Hexane was removed by using rotary evaporator(BUCHI R-210, Switzerland) and oil content was measured by using electronic balance $^{19)}$.

\subsection{Physicochemical Analysis}

Castor oil sample was further examined for its physical and chemical parameters. Moisture content of extracted oil was checked in order to determine the shelf life and purity of oil (method number: Ca 2C-25). Viscosity of oil was measured by viscometer (VM 3000 stabinger Anton Park, Austria) at $40^{\circ} \mathrm{C}$ using $5 \mathrm{ml}$ of sample. Refractive index and specific gravity of castor oil sample was also determined ${ }^{6)}$.

For the quality assessment of castor oil, the free fatty acid (FFA) (Ca 5a-40), iodine value (IV) (Cd 1-25), peroxide value (PV) (Cd 8-53) and saponification value (SV) (Cd 3-25) were measured according to official methods of $\operatorname{AOCS}^{18)}$.

\subsection{Fatty acid composition}

Fatty acid composition of castor oil was determined using GCMS (Agilent 5975 GC) with chemstation 6890 scale mode software. Fatty acid methyl esters were prepared according to IUPAC method No: $2.301^{20)}$. A HP-5MS (5\% phenyl methylsiloxane) capillary column $(30 \mathrm{~m} \times 0.25 \mathrm{~mm})$ was used to separate the esters. Sample was injected through Agilent auto sampler 7683-B injector (Agilent technologies, little fall, NY, USA). Column initial temperature was set as $150^{\circ} \mathrm{C}$ and maintained for one minute, and then it was raised to $220^{\circ} \mathrm{C}$ followed by the hold time of 15 min. Helium was used as carrier gas at flow rate of $1.5 \mathrm{ml} /$ min. $2 \mu \mathrm{L}$ of sample was injected using split mode injection system. For MS, electron impact mode $(70 \mathrm{eV})$ was used with a scan range of $50-550 \mathrm{~m} / z$. Finally, obtained chromatograms were compared with two libraries (NIST \& Wiley) which provided sufficient information regarding fatty acids in castor oil. 


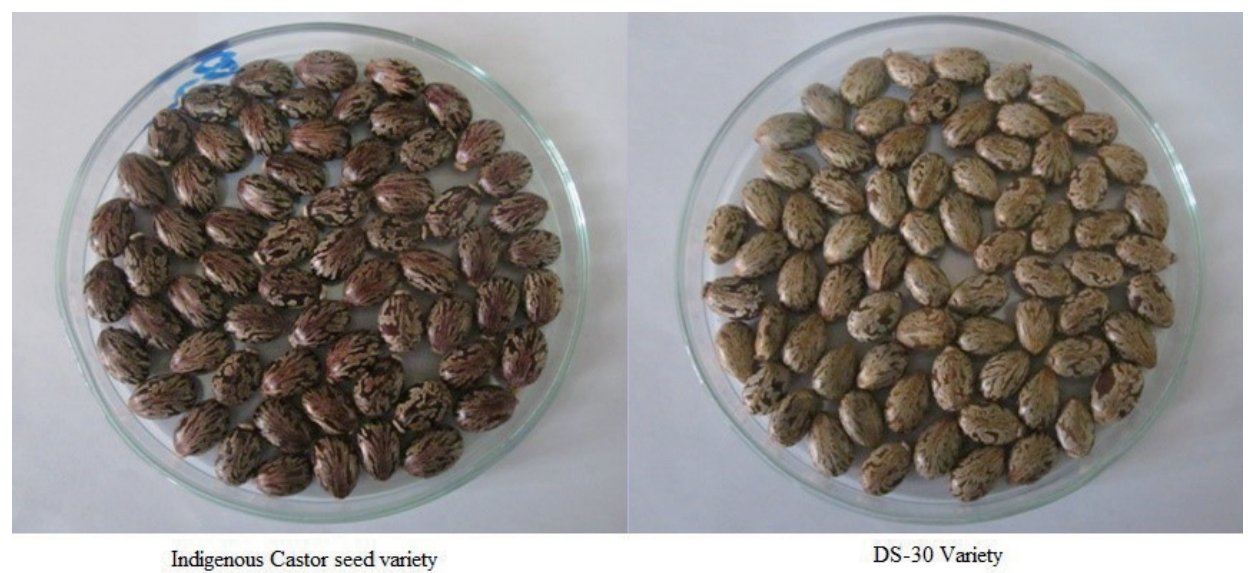

Fig. 1 Images of indigenous and DS-30 castor seed varieties.

Table 2 Physicochemical analysis of castor oil.

\begin{tabular}{lcc}
\hline \multicolumn{1}{c}{ Parameters } & Current Study & *ASTM \\
\hline Oil content $(\%)$ & 54.0 & - \\
Specific gravity at $28^{\circ} \mathrm{C}\left(\mathrm{g} / \mathrm{cm}^{-3}\right)$ & 0.953 & $0.957-0.968$ \\
Refractive Index at $28^{\circ} \mathrm{C}$ & 1.431 & $1.476-1.479$ \\
Viscosity at $28^{\circ} \mathrm{C}(\mathrm{mPas} . \mathrm{s})$ & 672.0 & $630-880$ \\
Moisture Content $(\%)$ & $0.32 \pm 0.00$ & $0.001-2.5$ \\
Free Fatty Acid $(\%)$ & $0.14 \pm 0.00$ & $0.4-4.0$ \\
Iodine Value $(\mathrm{gI} / \mathrm{l} / \mathrm{l00} \mathrm{g})$ & $83.61 \pm 1.79$ & $82-88$ \\
Peroxide Value $(\mathrm{meq} / \mathrm{Kg})$ & $2.25 \pm 0.08$ & $\leq 5$ \\
Saponification Value $(\mathrm{mgKOH} / \mathrm{g})$ & $186.0 \pm 2.18$ & $175-187$ \\
\hline $\mathrm{n}=3$ (mean $\pm \mathrm{SD})$ & & \\
*ASTM specifications for castor oil. & &
\end{tabular}

\subsection{Statistical Analysis}

Three samples of castor seeds were collected and each sample was analyzed thrice and obtained results were used as mean \pm Std by using Microsoft ${ }^{\circledR}$ excel 2008 software.

\section{RESULTS AND DISCUSSION}

Before detailed analysis of castor oil, first castor beans were undergone a physical examination. Figure 1 shows the picture of the indigenous high oil yielding castor seeds (current study) and DS-30 (registered variety). Morphologically both varieties showed some differences in size and color. Table 1 shows various physical parameters of castor seeds. The moisture content was calculated at $4.53 \%$, which was lower than a range reported in the literature $6.24-12.56 \%{ }^{21)}$. Ash content was determined at $6.44 \%$, which indicated that castor beans rich in minerals ${ }^{22)}$.

The three linear dimensions of seeds namely length, width and thickness were measured as $12.24 \mathrm{~mm}, 8.31 \mathrm{~mm}$ and $5.67 \mathrm{~mm}$, respectively. Individual seed weight and 100- seed weight were $0.38 \mathrm{~g}$ and $39.85 \mathrm{~g}$, respectively. Both these parameters can be helpful while dealing with a theoretical estimation of seed volume.

Table 2 shows the average of different quality parameters of castor oil. Highest oil content 54\% was determined from new variety as compared to registered variety DS-30 $(51 \%)^{16)}$. High oil content in current study is of great economical importance of the crop. Such difference in oil content is due to different levels of moisture, soil and temperature at different locations. Specific gravity, refractive index and viscosity of castor oil were calculated as $0.953 \mathrm{~g} /$ $\mathrm{cm}^{-3}, 1.431$ and $672.0 \mathrm{mPas} . \mathrm{s}$, respectively. The high viscosity of castor oil in comparison to other edible oils is possibly due to chain length, hydroxyl group of its fatty acids and hydrogen bonding among the hydroxyl groups. Castor oil possesses long chain carbon atoms and hydroxyl group on $12^{\text {th }}$ carbon in ricinoleic acid. Moisture content of oil was within the range of ASTM specifications, it was found to be $0.32 \%$. Quality of oil is conventionally expressed by percentage of FFA of the total oil/fat. It is calculated according to nature of oil as palmitic acid for palm oil, lauric acid for 


\section{T. Panhwar, S. A. Mahesar and, A. W. Mahesar et al.}

Table 3 Fatty Acid Composition and fragmentation pattern of indigenous castor oil.

\begin{tabular}{cclcccc}
\hline $\begin{array}{c}\text { Peak } \\
\text { No }\end{array}$ & $\begin{array}{c}\text { Retention } \\
\text { Time }(\mathrm{min})\end{array}$ & \multicolumn{1}{c}{ Fatty Acid } & $\begin{array}{c}\text { MW } \\
(\mathrm{g} / \mathrm{mol})\end{array}$ & $\begin{array}{c}\text { Base } \\
\text { peak }\end{array}$ & Characteristic ions & $\begin{array}{c}\text { Percentage } \\
(\%)\end{array}$ \\
\hline 1 & 14.66 & Palmitic Acid $\mathrm{C}_{16: 0}$ & 256.4 & 74 & $74,227,270$ & 0.31 \\
2 & 19.56 & Linoleic Acid $\mathrm{C}_{18: 2 \mathrm{n}, 12}$ & 280.4 & 67 & $67,263,294$ & 1.84 \\
3 & 19.76 & Oleic Acid $\mathrm{C}_{18: 1 n}$ & 282.0 & 55 & $55,264,296$ & 2.05 \\
4 & 19.88 & Oleic Acid $\mathrm{C}_{18: 1 n \text { n10 }}$ & 282.0 & 55 & $55,264,296$ & 0.22 \\
5 & 20.49 & Stearic Acid $\mathrm{C}_{18: 0}$ & 284.0 & 74 & $74,255,298$ & 0.45 \\
6 & 25.61 & Ricinoleic Acid $\mathrm{C}_{18: 1 \mathrm{n} \text { n, 12-OH }}$ & 298.0 & 55 & $55,183,279,297$ & 94.59 \\
7 & 26.28 & Eicosenoic Acid $\mathrm{C}_{20: 1 \mathrm{nn} 11}$ & 310.5 & 55 & $55,292,324$ & 0.53 \\
\hline
\end{tabular}

$\mathrm{n}=3($ mean $\pm \mathrm{SD})$

coconut and oleic acid for castor and all other oils ${ }^{23)}$. FFA of crude castor oil was calculated as $0.14 \%$, such a low value of FFA indicates the good quality of oil. Iodine value for indigenous castor oil was determined to be 83.61 $\mathrm{gI}_{2} / 100 \mathrm{~g}$. Investigated results for IV of castor oil was within the range of ASTM specifications and showed the presence of double bond in each fatty acid chain of castor oil which also classifies it as non-drying oil. Higher the iodine number, more the unsaturated fatty acid linkages present in an oil/fat ${ }^{24)}$ PV of oil is an important parameter that checks the extent of rancidity of oil during processing/ storage. High values of peroxide for oil relate its oxidation. PV for the castor oil was found at $2.25 \mathrm{meq} / \mathrm{kg}$, which also followed the ASTM specifications. SV of oil is determined for its use in soap and cosmetic industries. High SV make it valuable raw material for above mentioned industries ${ }^{25}$. SV for extracted crude oil was found to be $186.0 \mathrm{mg} \mathrm{KOH/g}$.

Table 3 represents the fatty acid composition and fragmentation pattern of extracted castor oil. Analysis of fatty acid composition in castor oil through GCMS showed that most abundant fatty acid in the castor oil was ricinoleic acid, which made up $94.59 \%$ of the total fatty acids. Other fatty acids present were palmitic acid $0.31 \%$, stearic acid $0.45 \%$, oleic acid (n-9) $2.05 \%$ and isomer of oleic acid (n-10) $0.22 \%$, linoleic acid $1.84 \%$ and eicosenoic acid $0.53 \%$. Figure 2 further clarifies through GCMS chromatogram showing the all detected fatty acids at their particular retention time. Ricinoleic acid is an important constituent of castor oil which makes it unique naturally occurring polyhydroxy compound. Presence of double bond and hydroxyl group in ricinoleic acid are responsible for versatile applications of castor oil in chemical industry. Its solubility in alcohol makes it good candidate for biodiesel production. Furthermore, the fragmentation pattern for detected fatty acids and their characteristic ions shows that for saturated fatty acids like palmitic and stearic, the base peak ion was at $74 \mathrm{~m} / z$ ratio. For monounsaturated fatty acids like oleic and eicosenoic, the characteristic peak appeared at $55 \mathrm{~m} / \mathrm{z}$ ratio. For biunsaturated fatty acids like linoleic acid, the base peak was at $67 \mathrm{~m} / \approx$ ratio. The fragmentation pattern

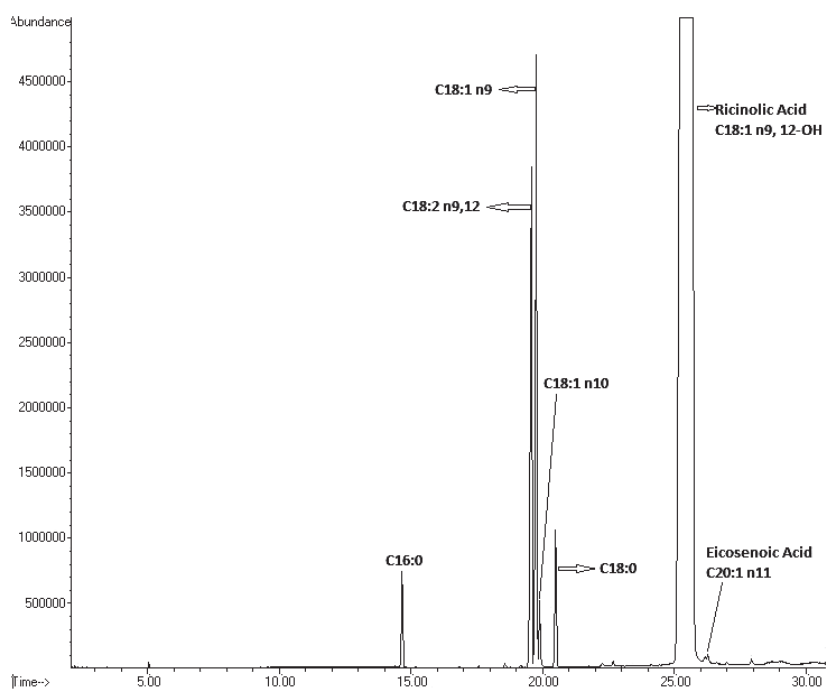

Fig. 2 GC-MS chromatogram of castor seed oil.

of oleic acid and its isomer showed that the molecular ion peak was at $296 \mathrm{~m} / z$, which undergone $\gamma$-hydrogen atom transfer and cleavage at $m / z 264$, while $m / z 55$ was due to $\alpha$-cleavage and double bond transfer. Both the isomers of oleic acid showed the same fragmentation pattern because of only shifting of double bond ${ }^{26)}$. The ricinoleic acid fragmentation pattern has shown the molecular ion peak at 296 $\mathrm{m} / \mathrm{z}$. During fragmentation cleavage in $\alpha$ to $12-\mathrm{OH}$ was observed. The base peak was at $55 \mathrm{~m} / z$, while removal of $\mathrm{H} 2 \mathrm{O}$ was observed at $279 \mathrm{~m} / \mathrm{z}$.

The determined percentage of ricinoleic acid in current indigenous variety (94.59\%) was higher than DS-30 $(86.67 \%)$ and Nigerian castor seed varieties ${ }^{27)}$, while the value resembles with the Mexican variety ${ }^{8}$, as represented in Table 4.

\section{Conclusion}

The castor oil is valuable because of its versatile applications in pharmaceutical, polymers and as renewable energy 
Table 4 Comparison of fatty acid composition of indigenous castor oil with other regions.

\begin{tabular}{|c|c|c|c|c|}
\hline Fatty Acid & $\begin{array}{l}\text { Current } \\
\text { Study }\end{array}$ & $(\mathrm{DS}-30)^{16)}$ & Nigeria $^{27)}$ & Mexico $^{8)}$ \\
\hline Palmitic & 0.31 & 1.96 & 0.46 & 0.23 \\
\hline Stearic & 0.45 & 0.81 & 0.52 & 0.72 \\
\hline Oleic $\mathrm{C}_{18: 1 n 9}$ & 2.05 & 3.81 & 2.28 & 2.08 \\
\hline Oleic $\mathrm{C}_{18: 1 n 10}$ & 0.22 & - & - & - \\
\hline Linoleic & 1.84 & 4.00 & 0.61 & 2.38 \\
\hline Linolenic & - & - & 0.33 & 0.29 \\
\hline Ricinoleic & 94.59 & 86.67 & 83.97 & 94.30 \\
\hline Eicosenoic & 0.53 & - & - & - \\
\hline Dihydroxy stearic acid & - & - & 0.24 & - \\
\hline Saturated fatty acids (SFA) & 0.76 & 2.77 & 0.98 & 0.95 \\
\hline Unsaturated fatty acids (UFA) & 99.23 & 94.48 & 87.43 & 99.05 \\
\hline
\end{tabular}

source. Besides oil, even the plant residue and oil cake are further used in biogas and fertilizers, respectively. Present study has carried out necessary examination of seed and oil characteristics of castor that will absolutely help other researchers to know the variations in parameters between different regions. The study has confirmed the presence of high percentage of ricinoleic acid $94.59 \%$ followed by oleic, linoleic, palmitic, stearic and eicosenoic acids. The determined quality parameters of castor oil were within the ASTM specifications. High oil content $54.0 \%$ is encouraging for its cultivation on large scale to increase the economy of the country. Castor as a crop has the excellent future in Pakistan, where large area of land lying vacant.

\section{Conflict of interest}

Authors have no any actual or potential conflict of interest including any financial, personal or other relationships with other people or organizations within three years of beginning the submitted work that could inappropriately influence, or be perceived to influence, their work.

\section{References}

1) Baldwin, B. S.; Cossar, R. D. Castor yield in response to planting date at four locations in the south-central United States. Ind. Crop. Prod. 29, 316-319 (2009).

2) Salimon, J.; Noor, D. A. M.; Nazrizawati, A. T.; Firdaus, M. Y. M.; Noraishah, A. Fatty acid composition and physicochemical properties of malaysian castor bean Ricinus communis L. seed oil. Sains Malaysiana 39, 761-764(2010).

3) Ogunniyi, D. S. Castor oil: A vital industrial raw mate- rial. Biores. Technol. 97, 1086-1091(2006).

4) Ramanjaneyulu, A. V.; Reddy, A. V.; Madhavi, A. The impact of sowing date and irrigation regime on castor (Ricinus communis L.) seed yield, oil quality characteristics and fatty acid composition during post rainy season in South India. Ind. Crop. Prod. 44, 25-31 (2013).

5) Bateni, H.; Karimi, K.; Zamani, A.; Benakashani, F. Castor plant for biodiesel, biogas, and ethanol production with a biorefinery processing perspective. Appl. Energ. 136, 14-22 (2014).

6) Akpan, U. G.; Jimoh, A.; Mohammed, A. D. Extraction, characterization and modification of castor seed oil. Leonardo J. Sci. 8, 43-52 (2006).

7) Conceição, M.; Candeia, R. A.; Silva, F. C.; Bezerra, A. F.; Fernandes, J. V. J.; Souza, A. G. Thermoanalytical characterization of castor oil biodiesel. Renew. Sust. Energ. Rev. 11, 964-975 (2007).

8) Perdomo, F. A.; Acosta-Osorio, A. A.; Herrera, G.; Vasco-Leal, J. F.; Mosquera-Artamonov, J. D.; Millan-Malo, B.; Rodriguez-Garcia, M. E. Physicochemical characterization of seven Mexican Ricinus communis L. seeds \& oil contents. Biomass Bioenerg. 48, 17-24 (2013).

9) Anjani, K. Castor genetic resources: a primary gene pool for exploitation. Ind. Crop. Prod. 35, 1-14 (2012).

10) Berman, P.; Nizri, S.; Wiesman, Z. Castor oil biodiesel and its blends as alternative fuel. Biomass Bioenerg. 35, 2861-2866 (2011).

11) Mutlu, H.; Meier, M. A. R. Castor oil as a renewable resource for the chemical industry. Eur. J. Lipid Sci. Technol. 112, 10-30 (2010).

12) Khan, N. A.; El Dessouky, H. Prospect of biodiesel in Pakistan. Renew. Sust. Energ. Rev. 13, 1576-1583 


\section{T. Panhwar, S. A. Mahesar and, A. W. Mahesar et al.}

(2009).

13) Algharib, A. M.; Kotb, E. A. Removal of strontium and cadmium from industrial wastewater using castor been and jojoba wastes. J. Biodiversity Environ. Sci. 5, 315-321 (2014).

14) Lavanya, C.; Murthy, I. Y. L. N.; Nagaraj, G.; Mukta, N. Prospects of castor (Ricinus communis L.) genotypes for biodiesel production in India. Biomass Bioenerg. 39, 204-209 (2012).

15) Ramos, D. S.; Tango, S. J.; Savi, A.; Leal, N. R. Variability for oil and fatty acid composition in castor bean varieties. J. Am. Oil Chem. Soc. 61, 111-114(1984).

16) Cheema, N. M. Yield and chemical composition of castor bean (Ricinus communis L.) as influenced by environment, Ph. D. thesis UAAR, Rawalpindi, Pakistan (2011).

17) Mirzaee, E.; Rafiee, S.; Keyhani, A. R.; Emam, D. Z.; Kheiralipour, K. Mass modeling of two varieties of apricot (Prunus armenaica L.) with some physical characteristics. Plant Omics J. 1, 37-43(2008).

18) AOCS Firestone, D. (6th Edition), Official Methods of Analysis, Association of Analytical Chemistry, Inc. Arlington, USA (2013).

19) Azadmard, D. S.; Savage, G. P.; Dutta, P. C. Sterol fractions in hazelnut and virgin olive oils and 4, 4'-dimethylsterols as possible markers for detection of adulteration of virgin olive oil. J. Am. Oil Chem. Soc. 82, 717725 (2005).

20) International Union of Pure and Applied Chemistry,
Standards methods for the analysis of oils, fats and derivatives, 6th edn. Pergamon Press, Oxford pp. 96-98 (1979).

21) Gharibzahedi, S. M. T.; Mousavi, S. M.; Ghahderijani, M. A survey on moisture-dependent physical properties of castor seed (Ricinus communis L.). Aust. J. Crop Sci. 5, 1-7 (2011).

22) Mathew, T. J.; Ndamitso, M. M.; Otori, A. A.; Shaba, E. Y.; Inobeme, A.; Adamu, A. Proximate and mineral compositions of seeds of some conventional and non conventional fruits in niger state, Nigeria. Acad. Res. Int. 5, 113-118(2014).

23) Gunstone, F. D. The Chemistry of Oils and Fats. Blackwell Publishing Ltd. pp. 1-112(2004).

24) Ziyadal, A. K.; Elhussien, S. A. Physical and chemical characteristics of citrulls lanatus var colocynthoid seed oil. J. Phys. Sci. 19, 69-75(2008).

25) Abayeh, O. J.; Aina, E. A.; Okuoghae. Oil content and oil quality characteristics of some Nigerian oil seeds. $J$. Pure Appl. Sci. 1, 17-23 (1998).

26) Qin, W. H.; Lan, H. X.; Shan, L. X.; Fang, H.; Xin, Z. Z.; Fen, M. Y. Gas chromatographic retention time rule and mass spectrometric fragmentation rule of fatty acids and its application in food. Chin. J. Anal. Chem. 35, 998-1003 (2007).

27) Nangbes, J. G.; Nvau, J. B.; Buba, W. M.; Zukdimma, A. N. Extraction and characterization of castor(Ricinus communis) seed oil. Int. J. Eng. Sci. 2, 105-109 (2013). 